Erianthus, Narenga, and Sclerostachya from Thailand and Vietnam. Cytologia 24: 342-347.

Rothwell, N. V. 1959. Aneuploidy in Claytonia virginica. Amer. Jour. Bot. 46:353-360.

SACHS, L. 1952. Chromosome mosaics in experimental amphiploids in the Triticinae. Heredity 6: 157-170.

SaUNTE, L. H. 1958. Chromosome variation in the Heleocharis palustris-uniglumis complex. Nature 181: $1019-1020$.

Sharma, A. K., and A. Sharma. 1956. Fixity in chromosome number of plants. Nature 177: 335-336.

SNOAD, B. 1955 . Somatic instability of chromosome number in Hymenocallis calathinum. Heredity 9: 129-134.

Strandhede, S. 1958. Eleocharis, subseries Palustres i Skandinavien och Finland. Bot. Not. 111: 228-236.
VAarama, A. 1949a. Permanent effect of colchicine on Ribes nigrum. Proc. 8th Int. Genet. Congress (Stockholm): 680-681.

. 1949b. Spindle abnormalities and variation in chromosome number in Ribes nigrum. Hereditas 35: $136-162$.

WITKUS, E. R. 1945. Endomitotic tapetal cell divisions in Spinacia. Amer. Jour. Bot. 32: $326-330$.

, Sr. J. B. Ferschl, and C. A. Berger. 1959. The cytology of Xanthisma texanum DC. V. Further observations on cytology and breeding behavior. Bull. Torrey Bot. Club 86: 300-307.

J. T. LowerY, AND C. A. Berger. 1955. The cytology of Xanthisma texanum DC. II. Additional chromosome types. Bull. Torrey Bot. Club 82: 367376 .

\title{
CELI WALL SYNTHESIS AND CELL ELONGATION IN OAT COLEOPTILE TISSUE ${ }^{1}$
}

\author{
Peter M. Ray \\ Department of Botany, University of Michigan, Ann Arbor, Michigan
}

\begin{abstract}
A B S T R A C T
Ray, Peter M. (U. Michigan, Ann Arbor.) Cell wall synthesis and cell elongation in oat coleoptile tissue. Amer. Jour. Bot. 49(9): 928-939. Illus. 1962.-Cell wall synthesis in oat coleoptile cylinders tends to run parallel with but not usually proportional to cell elongation both under promotion by auxin and sugar and under inhibition by supraoptimal auxin or sugar, or by a variety of other inhibitors. Inhibitors of elongation fall into 2 classes with respect to their effects on wall synthesis: (1) those which inhibit the 2 processes approximately equally (galactose, mannose, mannitol, azide, iodoacetate, dinitrophenol, low temperature, supraoptimal auxin) and (2) those which inhibit elongation percentagewise much more strongly than wall synthesis, so that as complete inhibition of elongation is approached, substantial wall synthesis continues $\left(\mathrm{Ca}^{+}+\right.$, fluoride, arsenite, mercurials). When coleoptile cylinders elongate in the absence of sugar, the cell walls appear to become markedly thinner, and in some experiments negligible increase in total wall material apparently occurs. However, the amount of $\alpha$-cellulose does rise. Increase in cell wall material occurs during elongation of cylinders at $2 \mathrm{C}$. The results are interpreted as indicating that during elongation the bulk of new cell wall material is added by apposition, but a certain proportion of the new material is probably introduced within the existing wall structure and induces its expansion.
\end{abstract}

Opinion has varied widely regarding the role of cell wall synthesis in the growth of plant cells. On the one hand, much botanical teaching has held that the primary wall "grows by intussusception" or addition of new material within its structure, an idea which dates back to Nägeli and Sachs. While some recent authors have favored the idea that wall synthesis may be involved in the mechanism of cell enlargement (Bonner and Thimann, 1950; Frey-Wyssling, 1950, 1957; Kivilaan, Beaman, and Bandurski, 1961), the prevalent view, as explained in the recent review by Setterfield and Bayley (1961),

1 Received for publication March 12, 1962.

This study was supported by National Science Foundation Grant NSF G-8705. I wish to thank David Baker, Kathleen Cramer and Albert Ruesink for help in some of the experiments. seems to be that wall synthesis is not the cause of cell enlargement, but on the contrary is induced $b y$ the occurrence of cell enlargement. Cytological evidence, also reviewed by Setterfield and Bayley (1961), suggests that wall synthesis in many growing cells occurs by apposition, the addition of new material at the wall surface. Since such addition would not affect the bonding forces within the existing wall which are supporting turgor stress, it would not be expected to cause wall expansion, but, if anything, to oppose expansion by strengthening the cell wall.

The present experiments were conducted to explore the quantitative relationship between cell wall synthesis and cell enlargment in oat coleoptile tissue. They extend the original observations on this subject made by Bonner (1934). 
Methods and materials-Oats (Avena sativa) of the variety 'Victory' (Svalöf) were soaked 2 $\mathrm{hr}$ in tap water and planted on moist filter paper at $26 \mathrm{C}$. They were irradiated with a 25 -w rubyred photographic safelight for $24 \mathrm{hr}$ and were kept in the dark thereafter. Coleoptiles were harvested under dim green light $\left(\lambda_{\max }\right.$ ca. $\left.540 \mathrm{~m} \mu\right)$ about $78 \mathrm{hr}$ after soaking, the coleoptiles used being $2-3 \mathrm{~cm}$ in length.

With a double-bladed cutter, a cylinder $8 \mathrm{~mm}$ long was cut from each coleoptile beginning 3 $\mathrm{mm}$ below the tip; the primary leaf was removed and the cylinders were floated in $1 \mathrm{ppm} \mathrm{MnSO}_{4}$ solution for $1-2 \mathrm{hr}$ in the dark. They were then transferred to 6-cm Petri dishes containing 4.0 $\mathrm{ml}$ of experimental solution, 15-20 cylinders per dish. At this time initial samples of cell wall material were prepared from some of the cylinders, after measuring their lengths. Cylinders were kept in the experimental solutions $20-24 \mathrm{hr}$ in the dark at $26 \mathrm{C}$, unless otherwise noted. The solutions contained $3 \mathrm{mg} /$ liter indoleacetic acid (IAA) and $0.1 \mathrm{~m}$ glucose unless indicated otherwise.

Cell wall preparations were made by crushing 15-20 coleoptile cylinders in water between two $5 \times 5 \times 0.25$ in. glass plates, applying manually about $50 \mathrm{lb}$ of force normal to the plates. By this means residues were obtained in which the cell wall structure of each cylinder remained as a coherent unit, which simplified the subsequent handling and weighing of the sample and the attainment and verification of complete recovery of the cell wall material. The residues were washed briefly with water, the wash water was decanted and the residues were soaked overnight in $50 \%$ $(\mathrm{w} / \mathrm{v})$ aqueous urea at room temperature; this removed microscopically visible remains of protoplasm from most of the cells, and lowered the protein content considerably (see below). The material was then washed 3 times with water and 3 times with $95 \%$ ethanol, allowing $15 \mathrm{~min}$ between each change of solution.

The individual sample (15-20 residues, $2-4$ mg) was placed on filter paper in a small Petri dish, dried at $60 \mathrm{C}$ for $1 \mathrm{hr}$ or more, and cooled in a desiccator over $\mathrm{CaCl}_{2}$. The product was white or occasionally pale buff in color; the residues cohered as a single mass. This was removed and rapidly weighed to $0.01 \mathrm{mg}$ on a Mettler M5 microbalance, the weight being taken about 30 sec after removal from the dish. The material is somewhat hygroscopic; the weight obtained by this method was found to include $4 \%$ water, by drying over $\mathrm{P}_{2} \mathrm{O}_{5}$ and weighing in weighing bottles. For speed and convenience direct weighing in air was used routinely. Upon redrying and reweighing this weight was reproducible normally to within $\pm 0.01 \mathrm{mg}$.

Cell wall preparations represented about $40 \%$ of the dry weight and $3 \%$ of the fresh weight of the coleoptile cylinders.
Nitrogen was determined by Kjeldahl digestion of the solid samples, by the method of Miller and Miller (1948), in $0.2 \mathrm{ml}$ of $1: 1 \mathrm{H}_{2} \mathrm{SO}_{4}$; the digest was diluted with $10 \mathrm{ml}$ water, a 4-ml aliquot was added to $1.3 \mathrm{ml}$ of Nessler's reagent, and the color was measured with a Klett colorimeter using a green or blue filter. The samples were not visibly turbid. $\left(\mathrm{NH}_{4}\right)_{2} \mathrm{SO}_{4}$ was used as standard. Protein was calculated as $6.2 \times \mathrm{N}$.

Urea extraction appeared to remove only protein, for the difference in weight of comparable wall preparations made with and without urea extraction was essentially equal to their difference in protein content. For example, with duplicate samples of 17 cylinders each, the differences were in one experiment $0.37 \mathrm{mg}$ weight and $0.35 \mathrm{mg}$ protein, and in another $0.33 \mathrm{mg}$ weight and $0.33 \mathrm{mg}$ protein (initial weight about $2.4 \mathrm{mg}$ ).

The cell wall preparations still generally contained $16-24 \%$ protein, which is probably largely protoplasmic contamination (ef. Kivilaan et al., 1959). The protein content of the cell wall preparations from isolated cylinders (Table 2) generally changed relatively little during elongation, and when increases did occur, these went parallel with the much larger changes in non-protein cell wall material, except in cases where turgor was lost, when protein content tended to increase abnormally. All data given apply to cylinders which were not flaccid, except where specifically indicated. Unless otherwise stated, increase in weight of the cell wall preparations above that of initial samples was used as the measure of wall synthesis.

To determine $\alpha$-cellulose, cell wall preparations were extracted with $0.05 \mathrm{~N}_{2} \mathrm{SO}_{4}$ at $100 \mathrm{C}$ for $2 \mathrm{hr}$, followed by $4 \mathrm{~N} \mathrm{KOH}$ at $25 \mathrm{C}$ for $8 \mathrm{hr}$. The residue was washed, dried and weighed to $\pm 1 \mu \mathrm{g}$ (it was not appreciably hygroscopic). This material gave mainly glucose, with a minor proportion of mannose and traces of xylose, upon hydrolysis (Ray, 1958).

It was found that all of the protein was removed in the acid and alkali extractions and could be recovered in the extracts. Therefore, in experiments in which $\alpha$-cellulose was determined, $\mathrm{N}$ was determined on the combined acid and alkali extracts, or aliquots thereof, by neutralizing, evaporating, and digesting with $\mathrm{H}_{2} \mathrm{SO}_{4}$ as described previously.

All data in the tables are expressed on a percylinder basis. The variation between replicate samples may be judged from the data given in Tables 6-8 and in the figures. In general the cell wall weights of replicate initial samples agreed within $2 \%$, although the initial value differed from experiment to experiment. Cell wall weights of replicate final samples often differed by 4 to $8 \%$ and sometimes more. The larger variations were usually correlated with differences in amount of elongation between different groups of cylin- 
ders. Most of the experiments were run using duplicate samples. To conserve space the means for each pair of samples are given in the tables as noted.

RESUlts-Figure 1 shows the time course of elongation and of increase in cell wall material of oat coleoptile cylinders kept in $0.1 \mathrm{~m}$ glucose or in glucose plus $3 \mathrm{mg} /$ liter IAA. A substantial promotion of wall synthesis by IAA is evident throughout the period covered, and is established quite positively by triplicate samples taken at the first determination $6 \mathrm{hr}$ after the start of the experiment.

The effect of different concentrations of IAA on elongation and wall synthesis is shown in Fig. 2 . The effect on synthesis parallels closely the effect on elongation in both the promotive and the inhibitory concentration ranges.
It is to be noted that auxin promotes elongation by a much larger factor than it promotes wall synthesis: optimal IAA increases the rate of elongation 3-6 fold, the rate of wall synthesis by $1.5-2$ fold.

Although promotion of coleoptile cell wall synthesis by auxin was found by Bonner (1934), Bayley and Setterfield (1957), Busse (1959), and Wightman and Neish (1959), and repeatedly in the present work, various experiments with $\mathrm{C}^{14}$ labelled sugar have been reported showing no promotion of total wall synthesis by auxin (Boroughs and Bonner, 1953; Ordin, Cleland and Bonner, 1955; Ordin and Bonner, 1957). The principal difference appears to be that the latter experiments were conducted with very dilute $\left(10^{-3} \mathrm{M}\right.$ or lower) sugar solutions, in which, as will be shown below, an amount of synthesis
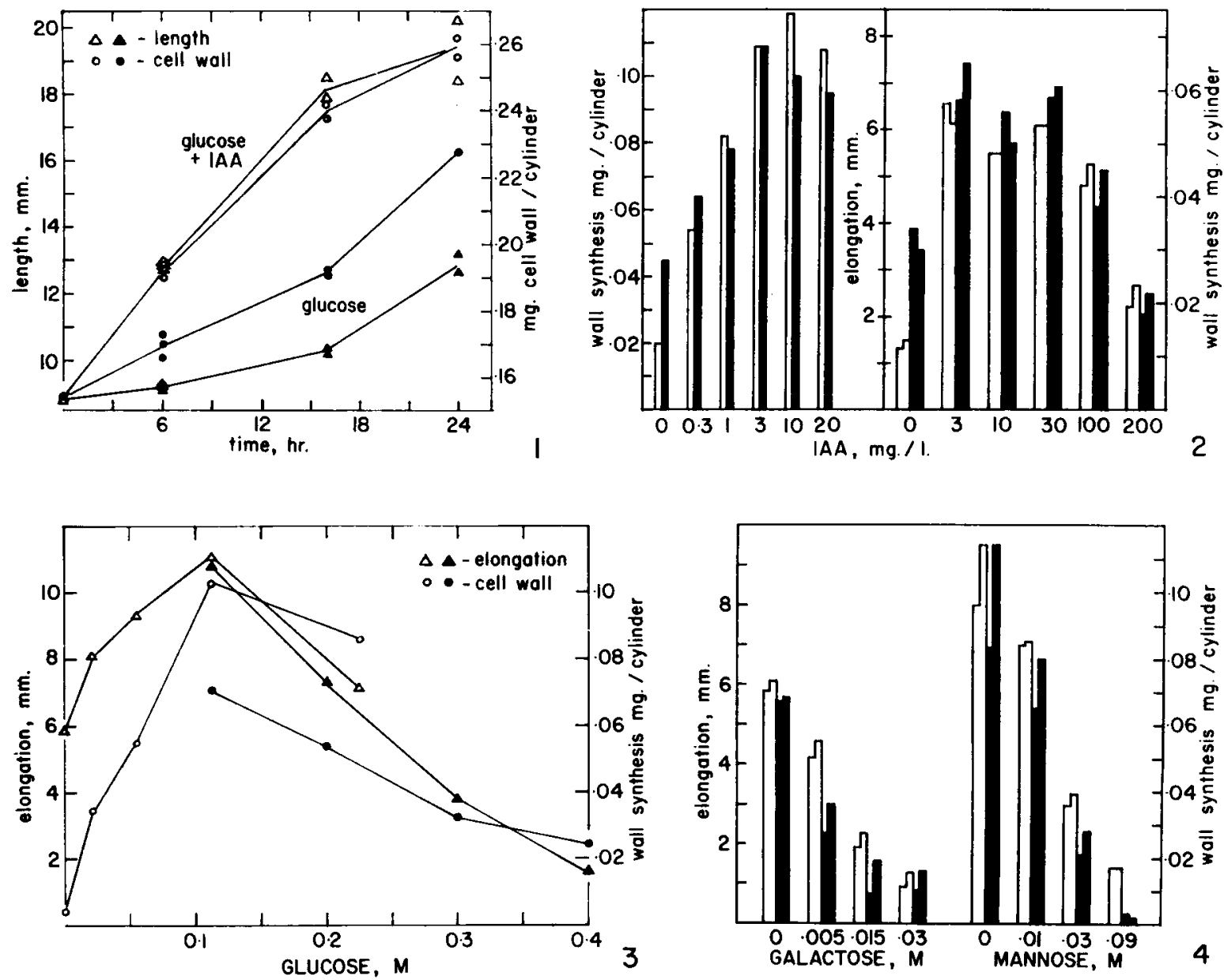

T Fig. 1-4. Elongation and increase in total cell wall in oat coleoptile cylinders.--Fig. 1. Time course of elongation and wall synthesis, in $0.1 \mathrm{M}$ glucose with and without $3 \mathrm{mg} /$ liter IAA. Triplicate samples of 15 cylinders at $6 \mathrm{hr}$, duplicate samples at other times and initially.-Fig. 2. Effect of IAA concentration, with $0.1 \mathrm{M}$ glucose. Two experiments of $19 \mathrm{hr}$ duration. Solid bars, wall synthesis; open bars, elongation. Step-shaped bars show results with duplicate samples.Fig. 3. Effect of glucose concentration. Two experiments of $20 \mathrm{hr}$ duration, shown by closed and open points respectively.Fig. 4. Effects of galactose and mannose (21 and $23 \mathrm{hr}$ duration, respectively) with 0.1 m glucose. Solid bars, wall synthesis; open bars, elongation. 
TABLE 1. Wall synthesis in attached coleoptile tissue

\begin{tabular}{|c|c|c|c|c|c|c|}
\hline Treatment & $\begin{array}{c}\text { Mean } \\
\text { length } \\
\text { mm }\end{array}$ & $\begin{array}{l}\text { Total } \\
\text { cell wall } \\
\mu \mathrm{g}\end{array}$ & $\begin{array}{c}\text { Wall prep. } \\
\text { protein } \\
\mu \mathrm{g}\end{array}$ & $\begin{array}{l}\text { Percent } \\
\text { protein }\end{array}$ & $\begin{array}{l}\text { Non- } \\
\text { protein } \\
\text { cell wall } \\
\quad \mu \mathrm{gb}^{\mathrm{b}}\end{array}$ & $\begin{array}{l}\text { Non- } \\
\text { protein } \\
\text { cell wall } \\
\mu \mathrm{g} / \mathrm{mm}\end{array}$ \\
\hline Initial sample & $8.9^{\mathrm{d}}$ & 126 & 25 & 19.8 & 101 & 11.4 \\
\hline No auxin & 13.6 & 201 & 37 & 18.4 & 164 & 12.0 \\
\hline $3 \mathrm{mg} /$ liter IAA in agar & 16.1 & 236 & 40 & 16.9 & 196 & 12.2 \\
\hline $0.1 \%$ IAA in lanolin & 19.3 & 282 & 48 & 17.0 & 234 & 12.1 \\
\hline Initial sample ${ }^{c}$ & $8.6^{\mathrm{d}}$ & 100 & 19 & 19.0 & 81 & 9.4 \\
\hline After growth ${ }^{c}$ & 12.0 & 102 & 16 & 15.6 & 86 & 7.2 \\
\hline
\end{tabular}

a Each sample consisted of $20-22$ cylinders. The method of treatment is described in the text. Growth period $24 \mathrm{hr}$.

b Total cell wall less wall prep. protein.

- Seeds were removed from these plants $6 \mathrm{hr}$ prior to cutting or marking; coleoptiles were not decapitated nor treated during the growth period.

d Length at time of crushing of initial samples.

which is substantial relative to the initially present amount of cell wall material does not occur. Under these conditions it is possible that limitation of synthesis by amount of substrate, and isotope dilution by endogenous substrates, could have affected the results. Auxin promotion of wall synthesis is observed when 0.1-m-labelled glucose is used as substrate. For example, $9.6-\mathrm{mm}$ eylinders were kept $12 \mathrm{hr}$ in uniformly $\mathrm{C}^{14}$-labelled glucose; the mean ( \pm avg deviation) c.p.m. for wall preparations from 6 cylinders without IAA was $1110 \pm 220$ c.p.m. (mean length $11.8 \mathrm{~mm}$ ), and with $3 \mathrm{mg} /$ liter IAA it was $2970 \pm 410$ c.p.m. (mean length $17.7 \mathrm{~mm}$ ).

TABLE 2. Changes in wall thickness and protein in coleoptile cylinders

\begin{tabular}{|c|c|c|c|c|c|c|}
\hline \multirow{2}{*}{\multicolumn{2}{|c|}{ Exp. Treatment ${ }^{a}$}} & \multirow{2}{*}{$\begin{array}{c}\text { Mean } \\
\text { length } \\
\mathrm{mm}\end{array}$} & \multirow{2}{*}{$\begin{array}{c}\text { Total } \\
\text { cell wall } \\
\mu \mathrm{g}\end{array}$} & \multirow{2}{*}{$\begin{array}{c}\text { Wall prep. } \\
\text { protein } \\
\mu \mathrm{g}\end{array}$} & \multicolumn{2}{|c|}{$\begin{array}{l}\text { Non-protein } \\
\text { cell wall }\end{array}$} \\
\hline & & & & & $\mu \mathrm{g}$ & $\mu \mathrm{g} / \mathrm{mm}$ \\
\hline \multirow[t]{4}{*}{1} & Initial sample & 8.6 & 133 & 24 & 109 & 12.7 \\
\hline & Control & 16.3 & 221 & 32 & 189 & 11.7 \\
\hline & Omit IAA & 11.0 & 189 & 28 & 161 & 14.6 \\
\hline & $\mathrm{CaCl}_{2} 0.01 \mathrm{M}$ & 9.5 & 187 & 28 & 159 & 16.7 \\
\hline \multirow[t]{6}{*}{2} & Initial sample & 8.8 & 152 & 34 & 118 & 14.5 \\
\hline & Control & 16.7 & 230 & 37 & 193 & 11.5 \\
\hline & $\mathrm{HgCl}_{2} 2 \times 10^{-4} \mathrm{M}$ & 9.5 & 201 & 38 & 163 & 17.2 \\
\hline & Phenylmercuric $\mathrm{Cl} 2 \times 10^{-5} \mathrm{M}$ & 9.5 & 187 & 35 & 152 & 16.0 \\
\hline & $\mathrm{Na}$ arsenite $3 \times 10^{-5} \mathrm{M}$ & 11.6 & 194 & 33 & 161 & 13.9 \\
\hline & $\mathrm{Na}$ iodoacetate $1.5 \times 10^{-4} \mathrm{M}$ & 13.0 & 196 & 37 & 159 & 12.2 \\
\hline \multirow[t]{4}{*}{3} & Initial sample & 8.9 & 177 & 48 & 129 & 14.5 \\
\hline & Control & 19.5 & 255 & 50 & 205 & 11.5 \\
\hline & Mannitol $0.16 \mathrm{M}$ & 12.4 & 209 & 49 & 160 & 12.9 \\
\hline & Mannitol $0.32 \mathrm{M}$ & 9.7 & 183 & 41 & 142 & 14.6 \\
\hline
\end{tabular}

a Control solution contained $0.1 \mathrm{~m}$ glucose and $3 \mathrm{mg} /$ liter IAA; other growth solutions modified as indicated. Each figure is the mean of duplicate samples of 15-20 coleoptile cylinders. Growth period $24 \mathrm{hr}$. 
TABLE 3. Inhibition of elongation and uall synthesis

\begin{tabular}{|c|c|c|c|}
\hline \multirow[b]{2}{*}{ Inhibitor } & \multirow[b]{2}{*}{ Conc. (M) } & \multicolumn{2}{|c|}{ Percent of controla } \\
\hline & & Elongation & Wall synth. \\
\hline Galactose & $\begin{array}{l}0.01 \\
0.03\end{array}$ & $\begin{array}{r}71 \\
8\end{array}$ & $\begin{array}{l}52 \\
13\end{array}$ \\
\hline Mannose & $\begin{array}{l}0.03 \\
0.09\end{array}$ & $\begin{array}{l}36 \\
16\end{array}$ & $\begin{array}{r}24 \\
2\end{array}$ \\
\hline Mannitol & $\begin{array}{l}0.08 \\
0.24 \\
0.32\end{array}$ & $\begin{array}{r}60 \\
15 \\
8\end{array}$ & $\begin{array}{r}63 \\
13 \\
8\end{array}$ \\
\hline $\begin{array}{c}\text { Carbowax } \\
4000\end{array}$ & $\begin{array}{l}0.08^{b} \\
0.24^{b}\end{array}$ & $\begin{array}{r}28 \\
2\end{array}$ & $\begin{array}{r}39 \\
5\end{array}$ \\
\hline $\mathrm{CaCl}_{2}$ & $\begin{array}{l}0.0003 \\
0.01\end{array}$ & $\begin{array}{r}62 \\
5\end{array}$ & $\begin{array}{l}82 \\
41\end{array}$ \\
\hline $\mathrm{MgCl}_{2}$ & $\begin{array}{l}0.005 \\
0.01\end{array}$ & $\begin{array}{l}64 \\
41\end{array}$ & $\begin{array}{l}94 \\
66\end{array}$ \\
\hline $\mathrm{LiCl}$ & 0.01 & 40 & 58 \\
\hline $\mathrm{FeCl}_{3}$ & 0.001 & $20^{\mathrm{c}}$ & 70 \\
\hline $\begin{aligned} & \mathrm{CoCl}_{2}(21 \mathrm{hr}) \\
&(16 \mathrm{hr})^{\mathrm{d}} \\
&(24 \mathrm{hr})^{\mathrm{d}}\end{aligned}$ & $\begin{array}{l}0.001 \\
0.00003 \\
0.00003\end{array}$ & $\begin{array}{r}40 \\
112 \\
131\end{array}$ & $\begin{array}{l}66 \\
83 \\
96\end{array}$ \\
\hline
\end{tabular}

a Controls contained $3 \mathrm{mg} /$ liter IAA and $0.1 \mathrm{~m}$ glucose. This table summarizes results of several experiments, of 16-24 hr duration, in which different inhibitors were tested. All data except those on $\mathrm{Mg}, \mathrm{Li}$ and $\mathrm{Fe}$ are based on duplicate initial, control and treated samples.

b Osmolar concentrations, determined by freezing-point depression. The lower concentration was $9 \% \mathrm{w} / \mathrm{v}$ and the higher concentration $16 \% \mathrm{w} / \mathrm{v}$.

c Loss of turgor at ends of some cylinders.

d These figures are from the same experiment, involving duplicate treated and control samples at each time of sampling.

Cell wall synthesis in coleoptile tissue attached to the seedling was investigated by marking off with India ink, using the same instrument as was employed for cutting cylinders, an 8-mm zone beginning $3 \mathrm{~mm}$ below the tip of an intact seedling whose coleoptile was $2-3 \mathrm{~cm}$ long. Coleoptile cylinders cut in the normal manner at the same time afforded the initial sample of cell wall material. The marked seedlings, with roots on moist filter paper, were then decapitated above the upper mark, and to some of the cut surfaces lanolin paste or agar blocks containing IAA were applied. The decapitation and application of IAA were repeated halfway through the experiment. After $24 \mathrm{hr}$, the coleoptiles were cut at the ink marks, and cell wall preparations were made from the (deleafed) cylinders corresponding to the original $8-\mathrm{mm}$ zone. The results, given in the upper part of Table 1 , show that IAA promoted the synthesis of cell walls in attached coleoptile tissue.

It may be seen in Table 1 that in attached coleoptiles cell wall synthesis was essentially proportional to elongation, for the amount of
TABLE 4. Effects of metabolic inhibitors

\begin{tabular}{|c|c|c|c|}
\hline \multirow[b]{2}{*}{ Inhibitor } & \multirow[b]{2}{*}{$\begin{array}{c}\text { Conc. } \\
\mathbf{M}\end{array}$} & \multicolumn{2}{|c|}{ Percent of control ${ }^{\mathbf{s}}$} \\
\hline & & $\begin{array}{c}\text { Elonga- } \\
\text { tion }\end{array}$ & $\begin{array}{c}\text { Wall } \\
\text { synthesis }\end{array}$ \\
\hline $\mathrm{NaN}_{3}$ & $\begin{array}{l}1 \times 10^{-4} \\
3 \times 10^{-4}\end{array}$ & $\begin{array}{l}68 \\
32\end{array}$ & $\begin{array}{l}69 \\
21\end{array}$ \\
\hline 2,4-dinitrophenol ${ }^{b}$ & $\begin{array}{l}1.2 \times 10^{-5} \\
2.5 \times 10^{-5} \\
3.5 \times 10^{-5}\end{array}$ & $\begin{array}{l}91 \\
73 \\
49^{c}\end{array}$ & $\begin{array}{l}69 \\
45 \\
36\end{array}$ \\
\hline $\mathrm{Na}$ iodoacetate & $\begin{array}{r}1 \times 10^{-4} \\
1.5 \times 10^{-4} \\
3 \times 10^{-4}\end{array}$ & $\begin{array}{l}86 \\
53 \\
19^{\mathrm{e}}\end{array}$ & $\begin{array}{l}72 \\
56 \\
44\end{array}$ \\
\hline $\mathrm{NaAsO}_{2}$ & $\begin{array}{l}5 \times 10^{-6} \\
3 \times 10^{-5} \\
5 \times 10^{-5}\end{array}$ & $\begin{array}{l}81 \\
35 \\
25\end{array}$ & $\begin{array}{l}96 \\
54 \\
48^{d}\end{array}$ \\
\hline Phenylmercuric $\mathrm{Cl}$ & $\begin{array}{l}3 \times 10^{-6} \\
2 \times 10^{-5}\end{array}$ & $\begin{array}{r}60 \\
9\end{array}$ & $\begin{array}{l}74 \\
45\end{array}$ \\
\hline $\begin{array}{l}\text { Na para-chloro- } \\
\text { mercuribenzoate }\end{array}$ & $5 \times 10^{-5}$ & 39 & 63 \\
\hline $\mathrm{HgCl}_{2}$ & $2 \times 10^{-4}$ & 9 & $54^{\mathrm{d}}$ \\
\hline $\mathrm{NaF}$ & $\begin{array}{l}1 \times 10^{-3} \\
4 \times 10^{-8}\end{array}$ & $\begin{array}{l}79 \\
25\end{array}$ & $\begin{array}{l}93 \\
48\end{array}$ \\
\hline 6-azauracile & $1 \times 10^{-2}$ & 77 & 34 \\
\hline 5-iodouracil & $1 \times 10^{-2}$ & 36 & 27 \\
\hline 8-azaadenine & $1 \times 10^{-2}$ & 24 & 13 \\
\hline
\end{tabular}

a Controls contained $0.1 \mathrm{~m}$ glucose and $3 \mathrm{mg} /$ liter IAA. Each figure is based on the mean of duplicate treated and control samples. This table summarizes the results of several experiments of $17-24 \mathrm{hr}$ duration, in which different inhibitors were tested.

b All solutions contained 0.02 м potassium phosphate, $\mathrm{pH}$ 5.0.

- Partial loss of turgor during the experiment.

d Corrected for change in protein content: shows percent of control increase in non-protein cell wall material.

- Cylinders were pretreated with $1.4 \times 10^{-2} \mathrm{~m}$ inhibitor for $7 \mathrm{hr}$ in absence of sugar and IAA, during which time controls remained in water. Then $0.1 \mathrm{~m}$ glucose and $3 \mathrm{mg} /$ liter IAA was added, bringing concentration of inhibitor to $10^{-2} \mathrm{M}$. After $15 \mathrm{hr}$ more, lengths were measured and wall preparations made.

cell wall material per $\mathrm{mm}$ of length remained nearly constant after elongation under all the treatments. This was found earlier for entire coleoptiles at this stage of growth (Thimann and Bonner, 1933; Preston and Clark, 1944).

However, with isolated coleoptile cylinders elongating rapidly in the presence of auxin and glucose, wall synthesis was percentagewise less than elongation, so that "wall thickness" ( $\mu \mathrm{g}$ per $\mathrm{mm}$ of length) decreased. The initial and control samples in Tables 2 and 5 provide data illustrating this point. In the absence of auxin, or under certain types of inhibitory treatment to be discussed below, synthesis sometimes went ahead of elongation and the apparent wall thickness increased. 
Thinning of the cell walls during elongation in auxin plus sugar was noted previously by Bayley and Setterfield (1957) and Busse (1959), with oat coleoptile cylinders, and by Christiansen and Thimann (1950) with pea stem segments. On the other hand, Bonner (1934) found that the cell walls apparently increased in thickness when coleoptile cylinders were grown in auxin plus fructose. In our experiments fructose gave results similar to glucose. There is reason, noted below, for thinking that Bonner's coleoptile cylinders contained considerably more endogenous substrates for wall synthesis than those used in the present experiments.

As recorded in the lower part of Table 1, wall synthesis in attached coleoptile could be greatly reduced, and thinning of the cell walls during elongation brought on by removing the seed from the plant several hours prior to beginning the experiment.

Effect of sugars-In Fig. 3 are shown the results of 2 experiments on the effect of glucose concentration on elongation and wall synthesis. Both processes exhibit an optimum at $0.1 \mathrm{~m}$ glucose, and are only slightly affected by concentrations of glucose below $0.025 \mathrm{M}$.

Among other sugars, sucrose and fructose gave effects similar to glucose. Arabinose and xylose alone supported only a slight amount of synthesis, and did not increase the rate of synthesis above that attainable using glucose alone.

Galactose and mannose inhibited both growth and synthesis strongly, as shown in Fig. 4. Since the inhibitory action occurs at concentrations
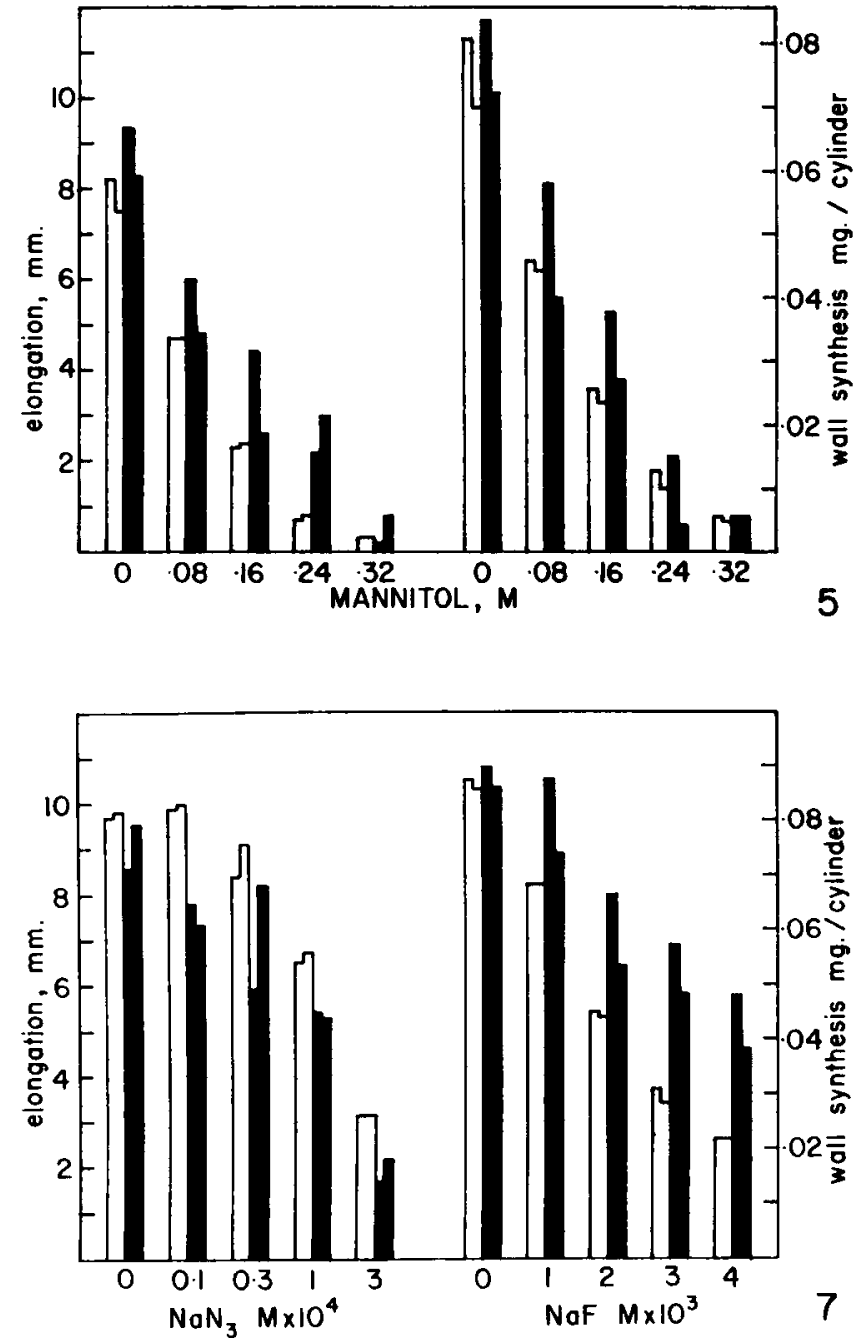
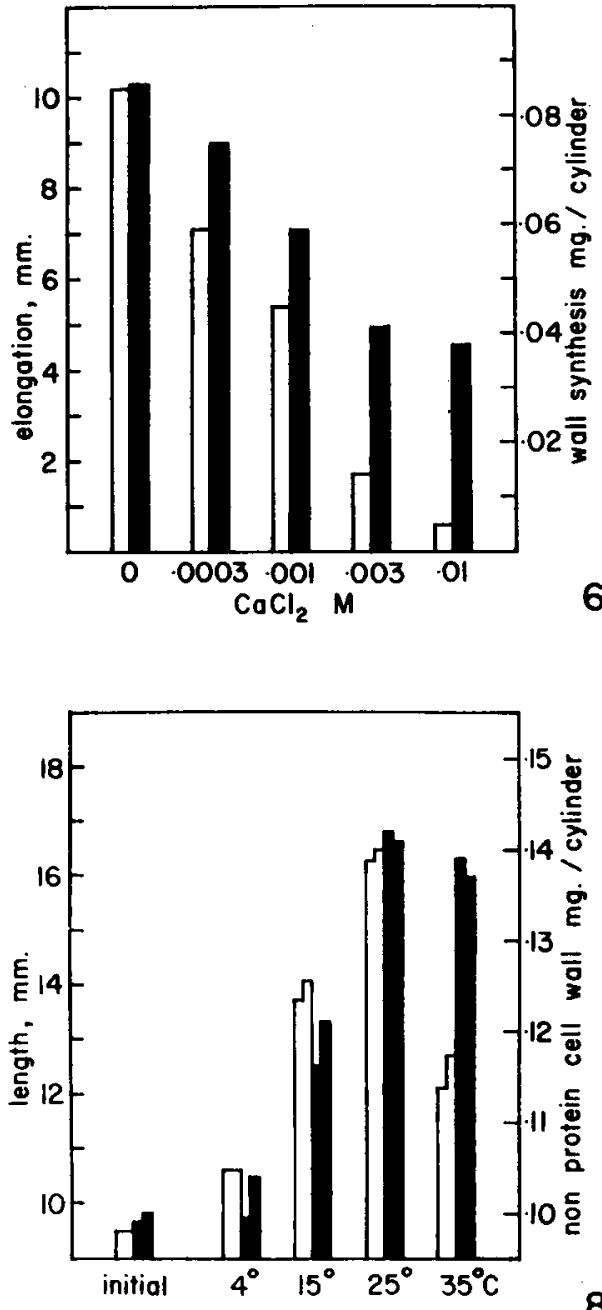

Fig. 5-8. Elongation (open bars) and wall synthesis (solid bars) in $0.1 \mathrm{M}$ glucose plus $3 \mathrm{mg} /$ liter IAA. Step-shaped bars show results with duplicate samples.-Fig. 5. Effect of mannitol. Two experiments, $18.5 \mathrm{hr}$ (left) and $21 \mathrm{hr}$ (right) duration.-Fig. 6. Effect of $\mathrm{CaCl}_{2}(19 \mathrm{hr})$. - Fig. 7. Effects of sodium azide $(17 \mathrm{hr})$ and sodium fluoride (22 hr).-Fig. 8 . Effect of temperature. Solid bars show total cell wall less wall-preparation protein, for initial samples and those taken after $22 \mathrm{hr}$ at the given temperatures. 
TABLE 5. Increase of $\alpha$-cellulose during elongation

\begin{tabular}{|c|c|c|c|c|c|c|c|}
\hline \multirow[b]{2}{*}{ Treatment } & \multirow{2}{*}{$\begin{array}{c}\text { Mean } \\
\text { length } \\
\text { mm }\end{array}$} & \multirow{2}{*}{$\begin{array}{l}\text { Total } \\
\text { cell wall } \\
\mu \mathrm{g}\end{array}$} & \multirow{2}{*}{$\begin{array}{l}\text { Wall prep. } \\
\text { protein } \\
\mu \mathrm{g}\end{array}$} & \multicolumn{2}{|c|}{$\begin{array}{l}\text { Non-protein } \\
\text { cell wall }\end{array}$} & \multicolumn{2}{|c|}{$\alpha$-cellulose } \\
\hline & & & & $\mu \mathrm{g}^{\mathrm{b}}$ & $\mu \mathrm{g} / \mathrm{mm}$ & $\mu \mathrm{g}$ & Percent ${ }^{\mathrm{c}}$ \\
\hline Initiald $^{d}$ & 8.7 & 132 & 29 & 103 & 11.9 & 34.8 & 33.8 \\
\hline IAA, glucose & 19.1 & 220 & 36 & 184 & 9.6 & 62.3 & 33.9 \\
\hline Plus NaF $4 \times 10^{-3} \mathrm{M}$ & 11.3 & 175 & 34 & 141 & 12.5 & 47.2 & 33.5 \\
\hline Initial ${ }^{\circ}$ & 8.8 & 153 & 35 & 118 & 13.4 & 36.4 & 30.8 \\
\hline IAA, glucose & 18.2 & 240 & 47 & 193 & 10.6 & 62.2 & 32.2 \\
\hline Glucose only & 10.3 & 192 & 33 & 159 & 15.4 & 48.0 & 30.6 \\
\hline
\end{tabular}

a Each figure is based on duplicate samples of 14 cylinders each.

b Total cell wall less wall prep. protein.

c Percent of non-protein cell wall.

d Duration of experiment $22 \mathrm{hr}$.

- Duration of experiment $16 \mathrm{hr}$.

5-10 times lower than are required to obtain comparable inhibitions with mannitol (l'ig. 5, below), it is presumed, in agreement with the conclusion of Ordin and Bonner (1957), that the effect of galactose and mannose is not an osmotic one. Ordin and Bonner found that concentrations of galactose which inhibited elongation did not depress respiration markedly; this was confirmed during the present work. They also reported inhibition of wall synthesis by galactose.

Inhibition by galactose and mannose is all the more interesting because these sugars are normal constituents of the coleoptile cell wall (Ray, 1958). It is noteworthy that the inhibitory action of both sugars on wall synthesis rather closely parallels their effects on elongation. Inhibition of synthesis was actually percentagewise somewhat stronger than inhibition of elongation (figures given in Table 3).

Osmotic effects-Mannitol, which is generally considered to inhibit elongation osmotically, also inhibits wall synthesis (Bayley and Setterfield, 1957; Ordin, 1958, 1960). As shown in Fig. 5 and Table 3 , it acts on elongation and synthesis nearly to the same degree; concentrations which inhibit growth completely almost completely suppress wall synthesis.

Osmotic inhibition by Carbowax 4000 (a polyethylene glycol) was also examined. Osmolarity of Carbowax 4000 solutions was determined by measuring their freezing-point depression. Table 3 shows that concentrations of Carbowax in the osmotic range inhibit elongation and wall synthesis strongly. For a given osmolar concentration the effect of Carbowax was somewhat stronger than that of mannitol. However, like mannitol, carbowax concentrations which completely inhibit elongation essentially prevent wall synthesis. It should be noted that such concentrations of both carbowax and mannitol are hypotonic, the concentration of the coleoptile cells being 0.4-
0.5 osmolar, so that plasmolysis is not involved. Completely inhibited cylinders still feel firm to the touch, and definitely have not lost turgor completely. This also indicates that Carbowax 4000 is not toxic.

Effects of cations-As shown in lig. 6 and Tables 2, 3, inhibition of elongation by $\mathrm{Ca}^{+}+$is accompanied by depression of wall synthesis, but the effect on synthesis is much weaker than the effect on elongation. In contrast with previously mentioned inhibitors, under complete inhibition of elongation some 40 percent of the control synthesis continues.

The much stronger effect of mannitol as compared with $\mathrm{Ca}^{+}+$on wall synthesis was noted with Jerusalem artichoke tissue by Adamson and Adamson (1959).

Stronger inhibition of elongation than wall synthesis was encountered with other inhibitory cations, viz. $\mathrm{Mg}^{++}, \mathrm{Li}^{++}, \mathrm{Fe}^{+++}$, and $\mathrm{Co}^{++}$, at supraoptimal concentration (Table 3).

Busse (1959) reported that the promotion of elongation by $\mathrm{Co}^{++}$, which begins after about 16 hr treatment with $3 \times 10^{-5} \mathrm{M} \mathrm{Co}^{++}$, is preceded by partial inhibition of cell wall synthesis. As recorded in Table 3 , this was confirmed, although the observed effect was not large.

Metabolic inhibitors -Table 4 and Fig. 7 show results with a variety of metabolic inhibitors. Those studied fell into 2 groups with regard to their relative effects on elongation and wall synthesis: (1) those which, like galactose, mannose or mannitol, inhibited both processes about equally or wall synthesis somewhat more strongly (azide, dinitrophenol, iodoacetate, purine and pyrimidine analogs) and (2) those which, like $\mathrm{Ca}^{++}$, inhibited elongation more strongly than synthesis, so that substantial synthesis continued even when elongation was nearly suppressed (fluoride, arsenite, mercurials). 
TABLE 6. Changes in cell wall material at 1-2 C

\begin{tabular}{|c|c|c|c|c|c|c|}
\hline \multirow{2}{*}{\multicolumn{2}{|c|}{ Treatment }} & \multirow[t]{2}{*}{$\begin{array}{l}\text { Length } \\
\mathrm{mm}\end{array}$} & \multirow{2}{*}{$\begin{array}{c}\text { Total } \\
\text { cell wall } \\
\mu \mathrm{g}\end{array}$} & \multirow{2}{*}{$\begin{array}{l}\text { Wall prep. } \\
\text { protein } \\
\qquad \mu \mathrm{g}\end{array}$} & \multirow{2}{*}{$\begin{array}{l}\text { Non-protein } \\
\text { cell wall } \\
\mu \mathrm{g}\end{array}$} & \multirow{2}{*}{$\begin{array}{c}\alpha \text {-cellulose } \\
\mu \mathrm{g}\end{array}$} \\
\hline & & & & & & \\
\hline Initial & & $8.22 \pm 0.02$ & $95.9 \pm 0.9$ & $17.7 \pm 0.3$ & $78.2 \pm 0.8$ & $28.9 \pm 0.4$ \\
\hline IAA & & $9.15 \pm 0.04$ & $102.2 \pm 2.3$ & $16.7 \pm 0.9$ & $85.5 \pm 1.3$ & $31.7 \pm 0.8$ \\
\hline Water & & $8.72 \pm 0.04$ & $100.8 \pm 2.3$ & $17.6 \pm 1.8$ & $83.2 \pm 0.6$ & $31.1 \pm 1.0$ \\
\hline Ratio - & $\frac{+ \text { IAA }}{- \text { IAA }}$ & 1.05 & 1.01 & 一 & 1.025 & 1.02 \\
\hline $\begin{array}{l}\text { Percent } \\
\text { in }\end{array}$ & $\begin{array}{l}\text { it increase over initial, } \\
\text { presence of IAA }\end{array}$ & 11.2 & 6.8 & 一 & 9.2 & 9.6 \\
\hline
\end{tabular}

s Figures show mean and average deviation for 5 replicate samples of 15 cylinders for each treatment. Duration of experiment $24 \mathrm{hr}$; no sugar present.

Christiansen and Thimann (1950) found that arsenite, fluoride and iodoacetate all inhibited elongation of pea stem segments more strongly than wall synthesis. However, the effect of iodoacetate on synthesis appears, as in the present findings, to have been significantly stronger than that of fluoride. Data in Table 4 indicating that at higher iodoacetate concentration it inhibits elongation more strongly than synthesis may be questioned because loss of turgor occurred.

Simultaneously applied uracil or uridine $(0.02$ M) did not reverse the inhibitory effect of 6azauracil; hence it is not demonstrated that this compound inhibits as an antimetabolite. In contrast with findings on bacterial cell wall synthesis (Rogers and Perkins 1960a, 1960b), $0.01 \mathrm{M}$ 5-fluorouracil inhibited neither wall synthesis nor elongation in this type of experiment.

Synthesis of $\alpha$-cellulose-Determinations of $\alpha$ cellulose from cylinders growing in the presence of glucose are given in Table 5. They show that the $\alpha$-cellulose content, expressed as percent of the non-protein cell wall material, remains essentially unchanged after varied amounts of synthesis have occurred, and whether or not IAA is present. This indicates that the newly added wall material has the same $\alpha$-cellulose content as the initial material.

This resembles the observation of Thimann and Bonner (1933) on intact coleoptiles of different lengths. It disagrees with the finding of Bayley and Setterfield (1957) that the $\alpha$-cellulose content was lower after wall synthesis by cylinders had occurred in the presence, as compared with the absence, of auxin.

Influence of temperature-Figure 8 shows the effect of temperature on elongation and wall synthesis. Below the temperature optimum the effect on both processes was similar. Above the optimum (i.e., at $35 \mathrm{C}$ ), elongation was inhibited much more than wall synthesis; however, at this temperature the tissue tends to lose turgor during the experiment.

Bonner (1934) concluded that no appreciable synthesis of wall material occurs during elongation of cylinders at $2 \mathrm{C}$, because the amount of wall material which he obtained from cylinders kept $20 \mathrm{hr}$ in auxin was not significantly greater than from cylinders kept for the same period in water. Since he did not determine the initial amount of wall material, this experiment does not actually show whether or not synthesis occurred (it indicates that auxin caused no promotion). Therefore, this question was reinvestigated.

Immediately after cutting, cylinders were brought into a cold room at $1-2 \mathrm{C}$, and under weak red light were transferred to water at this temperature. Replicate groups of 15 cylinders were then transferred to individual dishes of water or $3 \mathrm{mg} /$ liter IAA, or measured under a dissecting microscope and crushed in the cold room as initial samples. After $24 \mathrm{hr}$ in the dark at 1-2 $\mathrm{C}$ the water and auxin samples were measured and crushed in the cold room.

The results, given in Table 6, correspond rather well with the experiment of Bonner (1934), in that $11 \%$ elongation occurred in auxin (he reported $12-14 \%$ ), and although IAA caused a significant promotion of elongation, the resulting amount of wall material was only slightly greater than from cylinders kept for the same period in water. However, comparison with the initial samples shows that in both water and IAA an increase in amount of non-protein wall material and of $\alpha$-cellulose occurred.

Growth without sugar-Table 7 shows an experiment in which cylinders were induced to elongate at $26 \mathrm{C}$ without external sugar. In most such experiments, the increase in cell wall material was less than $10 \%$, despite elongations of $40-60 \%$, and was sometimes negligible. Such 
TABLE 7. Changes in wall material during elongation without sugar

\begin{tabular}{|c|c|c|c|c|c|c|c|}
\hline \multirow{2}{*}{$\begin{array}{c}\text { Time } \\
\mathrm{hr}\end{array}$} & \multirow{2}{*}{$\begin{array}{c}\text { Mean } \\
\text { length } \\
\mathrm{mm}\end{array}$} & \multirow{2}{*}{$\begin{array}{c}\text { Total } \\
\text { cell wall } \\
\mu \mathrm{g}\end{array}$} & \multirow{2}{*}{$\begin{array}{c}\text { Wall prep. } \\
\text { protein } \\
\mu \mathrm{g}\end{array}$} & \multirow{2}{*}{$\begin{array}{c}\text { Non- } \\
\text { protein } \\
\text { cell wall } \\
\quad \mu \mathrm{g}\end{array}$} & \multicolumn{2}{|c|}{$\alpha$-cellulose } & \multirow{2}{*}{$\begin{array}{l}\text { Hemi- } \\
\text { cellulose } \\
\mu^{\mathrm{c}}\end{array}$} \\
\hline & & & & & $\mu \mathrm{g}$ & percent $^{b}$ & \\
\hline 0 & 8.9 & $155 \pm 2$ & $30 \pm 0.2$ & $125 \pm 2$ & $37.9 \pm 0.4$ & $29.9 \pm 0.2$ & $86 \pm 2$ \\
\hline 3.5 & 11.1 & $164 \pm 5$ & $30 \pm 2$ & $134 \pm 3$ & $43.6 \pm 0.8$ & $32.7 \pm 0.4$ & $90 \pm 2$ \\
\hline 16 & 14.5 & $159 \pm 4$ & $24 \pm 1$ & $135 \pm 3$ & $51.3 \pm 1.4$ & $37.9 \pm 0.1$ & $84 \pm 2$ \\
\hline
\end{tabular}

alinders were grown in $3 \mathrm{mg} /$ liter IAA at $26 \mathrm{C}$. Figures show the mean and average deviation for 4 replicate samples of 15 cylinders for each time of sampling.

b Percent of non-protein cell wall material.

- Non-protein cell wall less $\alpha$-cellulose.

increase in wall material as did occur took place in the early hours of the experiment, further elongation apparently being accompanied by an insignificant change in amount of non-protein wall material. During the experiment of Table 7 the amount of cell wall per $\mathrm{mm}$ of length decreased from 14.0 to $9.3 \mu \mathrm{g}$.

These data agree with the statement of BennetClark (1956) that coleoptile cylinders without sugar may elongate without apparent increase in cell wall material. The tissues seem to contain little endogenous substrates for wall synthesis, or else do not employ the substrates they contain. It should be noted, however, that the wall preparations contain any starch present in the tissue, so conversion of starch into cell wall material would not be detected; Bishop, Bayley, and Setterfield (1958) obtained 1.2\% starch from an oat coleoptile cell wall preparation.

Occasional batches of cylinders increase more substantially in wall material in the absence of sugar. The largest increase observed during the present work was $19 \%$ in IAA; in water in the same experiment, the increase was $6.5 \%$ (4 replicate samples of 20 cylinders initially and for each treatment, $18 \mathrm{hr}$ growth). The cylinders used by Bonner (1934), who obtained about $16 \%$ more cell wall from eylinders which had been 6 $\mathrm{hr}$ in auxin than from those kept in water, probably contained even more endogenous substrates, perhaps because he did not soak the cylinders before beginning the expcriment.

Further data given in Table 7 show that in the absence of sugar the amount of $\alpha$-cellulose increases substantially, even when the total amount of non-protein wall material does not increase appreciably. Thus, unlike what was observed in the presence of glucose, the $\alpha$-cellulose content as percent of the non-protein wall material increases considerably.

Increase in $\alpha$-cellulose during elongation in the absence of sugar was promoted by IAA, although the effect was not large. Two experiments illustrating this are given in Table 8.

Discussion-It has repeatedly been stated that since elongation of coleoptile cylinders at $2 \mathrm{C}$ or in the absence of sugar is not accompanied by cell wall synthesis, wall synthesis cannot be the basis for cell enlargement.

The data given above indicate that in the absence of sugar, even though the total amount of cell wall material may remain constant, the

TABLE 8. Effect of IAA on increase in $\alpha$-cellulose during growth without sugar at $26 C$

\begin{tabular}{|c|c|c|c|c|c|c|c|c|c|c|}
\hline \multirow[b]{2}{*}{ Treatment } & \multirow{2}{*}{$\begin{array}{c}\text { Mean } \\
\text { length } \\
\mathrm{mm}\end{array}$} & \multicolumn{3}{|c|}{$\begin{array}{c}\text { Total cell wall } \\
\qquad \mu \mathrm{g}^{\mathrm{a}}\end{array}$} & \multicolumn{3}{|c|}{$\begin{array}{c}\alpha \text {-cellulose } \\
\mu \mathrm{g}^{\mathbf{a}}\end{array}$} & \multicolumn{3}{|c|}{$\begin{array}{c}\text { Percent } \\
\alpha \text {-cellulose } \\
\mathrm{a}^{\mathrm{a}}\end{array}$} \\
\hline & & 1 & 2 & mean & 1 & 2 & mean & 1 & 2 & mean \\
\hline Initial $^{b}$ & 9.0 & 141 & 130 & 136 & 41.7 & 39.0 & 40.4 & 29.6 & 30.0 & 29.8 \\
\hline Water & 10.6 & 138 & 133 & 136 & 46.6 & 45.0 & 45.8 & 33.8 & 33.8 & 33.8 \\
\hline IAA & 14.1 & 142 & 142 & 142 & 51.0 & 51.0 & 51.0 & 35.9 & 35.9 & 35.9 \\
\hline Initial ${ }^{\mathrm{c}}$ & 8.7 & 175 & 174 & 174 & 47.0 & 45.9 & 46.4 & 26.8 & 26.4 & 26.6 \\
\hline Water & 10.6 & 176 & 177 & 176 & 57.2 & 56.8 & 57.0 & 32.5 & 32.1 & 32.3 \\
\hline IAA & 12.9 & 174 & 176 & 175 & 57.8 & 60.0 & 58.9 & 33.2 & 34.1 & 33.6 \\
\hline
\end{tabular}

a Columns 1 and 2 show results with duplicate samples.

b Duration of experiment $19 \mathrm{hr} ; 15$ cylinders per sample.

c Duration of experiment $17.5 \mathrm{hr} ; 40$ cylinders per sample. IAA treatment $3 \mathrm{mg} /$ liter in both experiments. 
amount of $\alpha$-cellulose increases. At $2 \mathrm{C}$, the amount of both total cell wall and $\alpha$-cellulose slightly but definitely increases: relative to the slight elongation which occurs at this temperature the increase in amount of wall material (Table 6) is as great as in cylinders growing at 26 C. Furthermore, incorporation of labelled glucose into the cell wall is readily detected at 1-2 C (these experiments will be described elsewhere).

Therefore, it cannot be concluded that cell enlargement occurs without wall synthesis either in the absence of sugar or at $2 \mathrm{C}$.

Another reason which has been given (Bayley and Setterfield, 1957) for considering that wall synthesis is not the cause of cell enlargement is that mannitol concentrations which inhibit elongation also inhibit synthesis. Since mannitol was presumed to inhibit growth just by preventing water uptake, it seemed reasonable to conclude that wall synthesis is merely induced by cell elongation, and becomes promoted by auxin as a consequence of elongation being promoted.

It is now apparent that mannitol acts much more strongly on wall synthesis, relative to its action on elongation, than do a variety of other inhibitors of elongation $\left(\mathrm{Ca}^{+}+\right.$, arsenite, fluoride, mercurials). Whereas complete inhibition of elongation by mannitol or carbowax almost completely suppresses wall synthesis, a substantial amount of synthesis continues when elongation is inhibited by these other inhibitors.

Therefore, inhibition of wall synthesis by mannitol, or by other strong inhibitors of synthesis such as azide, dinitrophenol or galactose, is not simply a result of inhibition of elongation. It is not possible to judge with mannitol how much wall synthesis, if any, may be induced by the occurrence of wall expansion. And, on the contrary, it is possible that the inhibition of wall synthesis by mannitol may even be a cause of the inhibitory action of mannitol on growth.

Present and earlier data show that there is no fixed relation between wall synthesis, as a whole, and cell elongation. While synthesis occurs in proportion to elongation in attached coleoptile tissue, rapid elongation of isolated coleoptile cylinders is accompanied by thinning of the cell walls, especially in the absence of sugar. And on the other hand, when elongation is stopped by inhibitors such as $\mathrm{Ca}^{++}$, wall synthesis continues and the cell walls become thicker.

These facts suggest that a large proportion of the gross wall synthesis occurs by apposition, and hence needs bear no close quantitative relation to elongation. This would be in agreement with the electron-microscopic evidence which has been interpreted as indicating that cell wall deposition in elongating coleoptile parenchyma cells occurs at the inner surface of the cell wall (Wardrop, 1956; Setterfield and Bayley, 1957, 1958; Böhmer, 1958).
Despite the lack of a fixed relation between gross wall synthesis and cell elongation, the results nevertheless indicate a strong correlation between elongation and synthesis, since substantial effects on elongation and synthesis were almost invariably in the same direction (promotion of both or inhibition of both). With inhibitors which affect synthesis strongly (mannitol, galactose, mannose, azide, etc.) the effects on wall synthesis and elongation were percentagewise strikingly comparable, yet, as noted previously, these effects on synthesis cannot simply be the result of effects on elongation.

In the opinion of the author these observations can best be interpreted as indicating that a certain proportion of the new wall material is in fact introduced within the existing wall structure, leading to rearrangement of bonding forces between cell wall polysaccharides and thus to wall expansion and cell enlargement. Promotion of this type of synthesis by auxin, possibly reflected in the observed promotion of total wall synthesis by auxin, would then increase the rate of elongation. But because of a background of apposition synthesis constituting at least $50 \%$ of the total synthesis, the auxin effect on wall synthesis which brings about elongation would appear percentagewise to be small compared with the effect on elongation itself, as is observed.

Those inhibitors, such as $\mathrm{Ca}^{++}, \mathrm{F}, \mathrm{AsO}_{2}^{-}$ and mercurials, which lower wall synthesis to about $40-50 \%$ of the (auxin-treated) control when they inhibit elongation strongly, reduce wall synthesis to about the same level as in cylinders not treated with auxin. This suggests that these inhibitors, or at least some of them, may reverse the auxin promotion of synthesis. They may, then, inhibit that fraction of wall synthesis which is concerned with cell elongation, but not apposition synthesis. On the other hand, inhibitors which affect cell wall synthesis as a whole would be expected to act about as strongly on elongation as on wall synthesis according to the above hypothesis, as is observed. This would be true whether such inhibitors act by depressing synthetic metabolism generally (azide, dinitrophenol, low temperature) or by specifically inhibiting wall synthesis (galactose, mannose, mannitol).

That at least some of the newly added wall material may become incorporated within the existing wall structure in oat coleoptile cells is indicated by the autoradiographic evidence of Setterfield and Bayley (1959). Although in rapidly elongating coleoptile cylinders about $50 \%$ of the total wall synthesis is due (directly or indirectly) to auxin promotion, the proportion of the new material which becomes incorporated within the wall and is involved in the mechanism of wall expansion may not be as large as this. This is because some of the increase in synthesis caused by auxin may, indeed, be induced by the occur- 
rence of cell enlargement, though it is not as yet possible to judge what proportion of the increase is of this nature.

The fact that the cell walls may become markedly thinner during elongation suggests that the introduction of a given percent of new material can induce a considerably larger percent expansion. But even in the case of elongation without sugar, where the divergence between wall synthesis and elongation is greatest, this discrepancy is not so extreme when considered in terms of $\alpha$-cellulose: for example in Table 7, $39 \%$ increase in $\alpha$-cellulose and $63 \%$ elongation, and similar data in Table 8.

The idea that only a fraction of the total wall synthesis is involved in elongation, and that auxin promotes synthesis of this fraction, is in harmony with the evidence that auxin promotes synthesis of water-soluble polyuronide components of the cell wall (Albersheim and Bonner, 1959). These pectin fractions constitute less than $1 \%$ of the cell wall. It seems noteworthy that in the presence of an adequate amount of sugar, auxin can promote total wall synthesis and synthesis of $\alpha$-cellulose, which constitutes some $30 \%$ of the cell wall, at least as strongly as auxin has been observed to promote synthesis of watersoluble pectins. Any action which the pectic compounds may have in bringing about wall expansion most likely must be the result of their entering within the cell wall structure and affecting bonding forces within it; by the same token it seems probable that at least some of the other, quantitatively more prominent cell wall polysaccharides would enter within the cell wall structure and become involved in the mechanism of wall expansion and the effect of auxin thereon. The fraction of wall synthesis which is effective in causing cell enlargement would then be connected more with the manner of deposition rather than with a specific chemical fraction.

The observed effects of auxin on rate of synthesis of wall substances could simply be consequences of an auxin action to cause increased incorporation of new polysaccharides within the cell wall structure as opposed to deposition at the surface. If sufficient amounts of substrates were available, such incorporation would add to apposition synthesis so that a net promotion of wall polysaccharide synthesis would be seen. However, in the absence of adequate amounts of substrates for wall synthesis, such as in dilute sugar solutions or without added sugar, this same kind of auxin action would divert synthesis from apposition to incorporation. In this case a conspicuous promotion of cell elongation by auxin might be accompanied by a slight or even negligible increase in net synthesis of individual wall substances, as in Tables 6 and 8 , even though a significant effect on how they are being deposited could be occurring. It does not seem likely that slight net effects on synthesis, such as those seen in Tables 6 or 8 , could in themselves be responsible for the large auxin effect on elongation.

This concept should be helpful in making it clear that, although promotion of particular biochemical processes by auxin is valuable evidence regarding its action, auxin may be affecting significantly a biochemical process involved in growth even though a net promotion of this process is not observed under particular experimental conditions; questions of ultrastructure also enter in. This makes it impossible to eliminate, simply by the auxin-promotion criterion, cell wall synthesis as a factor of significance in cell enlargement.

The author does not think that an action of auxin on cell wall synthesis is necessarily? a primary action of auxin; effects on cell wall synthesis which are responsible for effects on cell elongation could be the result of some other primary action within the cell.

\section{LITERATURE CITED}

Adamson, D., and H. Adamson. 1959. Effect of reduced expansion and turgor on cell-wall formation in Jerusalem artichoke tissue. Proc. 9th Intern. Bot. Congr., Montreal, 2: 1 .

Albersherm, P., and J. Bonner. 1959. Metabolism and hormonal control of pectic substances. Jour. Biol. Chem. 234: 3105-3108.

Bayley, S. T., and G. SETrerfield. 1957. The influence of mannitol and auxin on growth of cell walls in Avena coleoptiles. Ann. Bot., N. S., 21 : 633-641.

BenNet-Clark, T. A. 1956. Salt accumulation and mode of action of auxin. A preliminary hypothesis, p. 284-291. In IR. I. Wain and F. Wightman, [ed.], The chemistry and mode of action of plant growth substances. Butterworth's Scientific Publs., London.

Bishop, C. T., S. T. Bayley, and G. SeTTerfeld. 1958. Chemical constitution of the primary cell walls of Avena coleoptiles. Plant Physiol. 33: 283-289.

BöHmer, H. 1958. Untersuchungen über das Wachstum und den Feinbau der Zellwände in der Avena-koleoptile. Planta 50: 461-497.

Bonner, J. 1934. Studies on the growth hormone of plants. V. The relation of cell elongation to cell wall formation. Proc. Natl. Acad Sci. (U.S.) 20: 393-397.

Bonner, W. D., and K. V. Thimann. 1950. Studies on the growth and inhibition of isolated plant parts. III. The action of some inhibitors concerned with pyruvate metabolism. Amer. Jour. Bot. 37: 66-75.

Boroughs, H., AND J. BonNER. 1953. Effects of indoleacetic acid on metabolic pathways. Arch. Biochem. Biophys. 46: 279-290.

Busse, M. 1959. Utber die Wirkungen von Kobalt auf Streckung, Atmung und Substanzeinbau in die Zellwand bei Avenakoleoptilen. Planta 53: 25-44.

Christiansen, G. S., and K. V. Thimans. 1950. The metabolism of stem tissue during growth and its inhibition. I. Carbohydrates. Arch. Biochem. 26: 230247.

Frey-Wyssliva, A. 1950. Physiology of cell wall growth. Ann. Rev. Plant Physiol. 1: 169-182.

- 1957. Macromolecules in cell structure. Harvard Univ. Press, Cambridge, Mass.

Kivilaan, A., T. C. BEaman, and R. S. Bandurski. 1959. A partial chemical characterization of maize 
coleoptile cell walls prepared with the aid of a continually renewable filter. Nature 184: B. A. 81-82.

- - - AND —- 1961. Enzymatic activities associated with cell wall preparations from corn coleoptiles. Plant Physiol. 36: 605-610.

Miller, G. L., and E. Miller. 1948. Determination of nitrogen in biological materials. Anal. Chem. 20: 481-488.

Ordin, L. 1958. The effect of water stress on cell wall metabolism of plant tissue, p. $553-564$. In R. C. Extermann, [ed.], Radioisotopes in scientific research. Vol. 4. Pergamon Press, New York.

-1 1960. Effect of water stress on cell wall metabolism of Avena coleoptile tissue. Plant Physiol. 35: $443-450$.

- AND J. Bonner. 1957. Effect of galactose on growth and metabolism of Avena coleoptile sections. Plant Physiol. 32: 212-215.

, R. Cleland, and J. Bonner. 1955. Influence of auxin on cell-wall metabolism. Proc. Natl. Acad. Sci. (U.S.) 41 : 1023-1029.

Preston, R. D., ANd C. S. Clakk. 1944. Wall structure and growth. II. Wall deposition in Avena coleoptiles. Proc. Leeds Phil. Lit. Soc., Sci. Sec., 4: 201-214.

RAY, P. M. 1958. Composition of cell walls of Avena coleoptiles. Plant Physiol. 33(Suppl.): xlvii.
Rogers, H. J., And H. R. Perkins. 1960a. The effect of 5-fluorouracil and other pyrimidine and purine analogues on cell-wall synthesis and the accumulation of amino sugar in Staphylococcus aureus. Biochem. Jour. 74: $6 \mathrm{P}$. , AND - 1960b. 5-Fluorouracil and mucopeptide biosynthesis by Slaphylococcus aureus. Biochem. Jour. $77: 448-459$.

SeitTerfield, G., and S. T. Bayley. 1957. Studies on the mechanism of deposition and extension of primary cell walls. Can. Jour. Bot. 35: 435-444.

— AND - - 1958. Arrangement of cellulose microfibrils in walls of elongating parenchyma cells. Jour. Biochem. Biophys. Cytol. 4: 377-382.

— - AND . 1959. Deposition of cell walls in oat coleoptiles. Can. Jour. Bot. 37: 861-870. -, AND - - . 1961. Structure and physiology of cell walls. Ann. Rev. Plant Physiol. 12: 35-62.

Thrmann, K. V., and J. Bonner. 1933. The mechanism of the action of the growth substance of plants. Proc. Roy. Soc. (Lond.), B, 113: 126-149.

WARDROP, A. B. 1956. The nature of surface growth in plant cells. Austr. Jour. Bot. 4: 193-199.

Wighrman, F., and A. C. Neish. 1959. The influence of plant-growth regulators on cell-wall metabolism. Proc. 9th Intern. Bot. Congr., Montreal, 2: 430. 